\title{
The Future eTourism intermediaries
}

\author{
Dimitrios Buhalis ${ }^{1}$, Maria Cristina Licata ${ }^{2}$
}

${ }^{1}$ Course Leader MSc in eTourism, School of Management Studies for The Service Sector, University of Surrey, Guildford, GU2 7XH, UK

d.buhalis@surrey.ac.uk

${ }^{2}$ Genesys Information Limited

Clarendon House, 125 Shenley Road,Borehamwood, Herts WD6 1AG, UK cristina.licata@genesysinformation.com

Acknowledgement: The authors would like to acknowledge Paul Richer and Dr Karsten Kärcher (Genesys Information Limited) for their contribution to this paper.

Note: An earlier version of this paper was presented at the ENTER2001 conference in Montreal, Canada. 


\title{
The Future eTourism intermediaries
}

Keywords: eTourism, Internet, intermediaries, disintermediation, Computer Reservation Systems, Global Distribution Systems, Digital TV, mobile commerce, Electronic Intermediaries

\begin{abstract}
Hitherto, the travel distribution role has been performed by traditional Outgoing Travel Agents (OTAs), Tour Operators (Tos) and Incoming Travel Agencies (ITAs). They were supported by Computer Reservation Systems (CRSs), Global Distribution Systems (GDSs) or tour operators' Videotext systems (or Leisure Travel Networks). These traditional electronic intermediaries (or 'eMediaries'), particularly GDSs, progressively consolidated their position. The Internet created the conditions for the emergence of new eMediaries, based on three ePlatforms, namely the Internet, Interactive Digital Television (IDTV) and mobile devices. New eMediaries include a wide range of organisations including suppliers (eg airlines, hotels etc) selling direct on the Internet by allowing users to access directly their reservation systems; web-based travel agents; Internet portals and vortals, and auction sites. The expected proliferation of Digital TV and mCommerce will gradually intensify competition further. As a result, traditional eMediaries must reengineer their business processes in order to survive and remain competitive. This exploratory research identifies experts' opinions on the future of both new and traditional eMediaries as well as the evolution of their business models.
\end{abstract}

\section{Introduction}

In the last few decades, Information Communication Technologies (ICTs) have deeply affected the way business is performed and the way that organisations compete (Porter, 1985, 2001; Porter and Millar,1985). The tourism and travel industries were particularly affected by these developments and in particular the way organisations distributed their tourism products in the marketplace (Poon,1993; Buhalis, Tjoa, Jafari,1998; Buhalis, Schertler,1999; Fesenmaier, Klein, Buhalis, D. 2000; Sheldon, Wöber, Fesenmaier, 2001). Traditionally the travel distribution role has been performed by outbound travel agencies (OTAs), tour operators (TOs) and inbound travel agents or handling agencies (ITAs) (Buhalis and Laws, 2001). They were supported by Computer Reservation Systems (CRSs), Global Distribution Systems (GDSs) or tour operators' Videotext systems (Leisure Travel Networks) (Karcher,1997,1998; Bordat,1999). In addition, tour operators used teletext to display late deals and special offers directly to consumers' TV. These traditional electronic intermediaries (or 'eMediaries'), particularly GDSs, progressively consolidated their position to four major systems, namely SABRE, AMADEUS, GALILEO, WORLDSPAN (Kärcher,1996; French, 1998; Copeland, 1991; Copeland and McKenney,1988; Truitt, Teye and Farris, 1991; Archdale, 1996; Sheldon, 1997; Hawkins, Leventhal, \& Oden, 1996; WTO,1995). This was due to their predominance as the largest existing repositories of travel stock information, with backing from the travel suppliers that had created and funded them. This illustrated in Figure 1, where Leiper's (1985) tourism system is used to explain the ICT supported distribution channel. The figure demonstrates that the tourism system is composed by the place of consumers' origin and the destination, with a number of tourism firms offering their services. In the transit region there are transportation companies and traditional intermediaries supported by GDSs, Teletext and Viewdata.

However, the Internet and electronic Commerce (eCommerce) developments in the late 1990s and the adoption of Tourism as one of the prime B2B (Business to Business) and B2C (Business to Consumers) application has changed the situation rapidly (Buhalis,1998; O'Connor,1999; Smith and Jenner,1998). The development of advent of the Internet as a universal and interactive means of communication, and a parallel change in consumer behaviour and attitude, have therefore shifted the traditional way tourism and travel products are distributed (Werthner and Klein,1999; 
O'Connor and Frew,2000). Increasingly, consumers can undertake their entire tourism product search and booking on-line and therefore the role of eMediaries has been changing dramatically.

\section{Figure 1: Old eTourism Intermediaries}

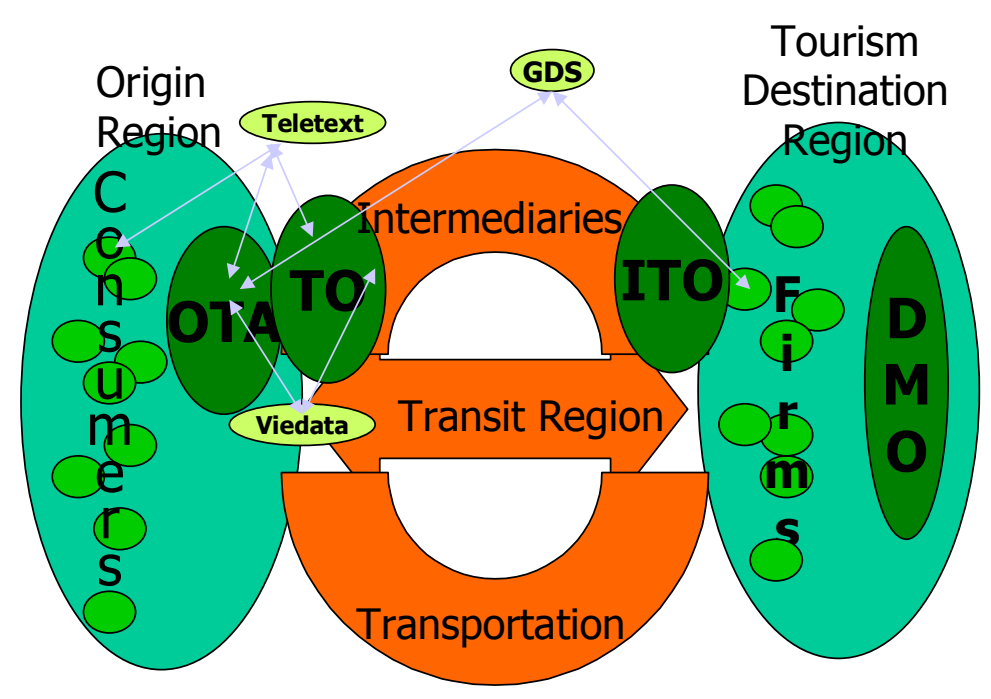

The Internet is widely used as a means to deliver up-to-date content. As a result it created the conditions for the emergence of a wide range of new tourism eMediaries. The proliferation of eMediaries followed a period of euphoria when a great member of players hoped that they will generate a high volume of profit by targeting the tourism industry. Tourism suppliers (particularly airlines, car rental and hotels chains) took advantage of the new opportunities and developed eCommerce applications by allowing users to access directly their reservation systems. This included single supplier provisions, such as British Airways (www.britishairways.com), Marriott Hotels (www.marriott.com), Avis (www.avis.com) as well as multi-supplier web pages that emerged to support airlines disintermediating travel agencies (e.g. www.opodo.com, www.orbitz.com). In addition, several destinations developed Destination Management Systems (DMSs) to distribute their smaller properties and to present the destination as a holistic entity (eg www.tiscover.com, www.holland.com). A number of web-based travel agencies also emerged (e.g. Expedia.com, ebookers.com, Travelocity.com) whilst off-line agencies developed their on-line provision (e.g. www.thomascook.com, www.lunnpoly.com). Internet portals (e.g. Yahoo, Altavista, Excite) and vertical portals (or vortals) (e.g. www.ski.com, www.golfonline.com, www.tennis.com) also developed on-line travel distribution, often by sourcing their travel content from external online agents and suppliers. Media companies such as newspapers (travel.telegraph.co.uk) and television networks (www.cnn.com/travel) gradually integrated their off-line with their on-line provision and expanded to include eCommerce capabilities on their sites. On-line last minute agencies emerged to enable distressed inventory to be distributed efficiently (e.g. www.lastminute.com). Priceline.com reversed the pricing method and allowed passengers to search for suppliers that would be prepared to serve them for the amount of money that consumers specified. Finally, a number of sites (e.g. www.QXL.com, www.ebay.com) specialised in the sale of distress stock through auctions. The proliferation of eMediaries confused consumers and the industry as many marketing managers rushed to ensure that their products were represented in all distribution channels and realised the difficulty and cost of doing so.

Most of these emerging eMediaries are new entrants often owned or powered by existing nontourism organisations (e.g. Microsoft's Expedia). The major GDSs, following a period of inertia realised the dramatic changes, are gradually entering the online market by developing interfaces for consumers [e.g. Travelocity.com (owned by Sabre) and TRIP.com (owned by Galileo)], 
although they are still less proactive than newer players (O'Connor, 1999; Buhalis, 1998,2000; Richer \& O'Neill-Dunne, 1999). In addition to the above Internet-based new eMediaries, there is a gradual emergence of further new eMediaries using mobile devices (mobile phones, palm tops etc as well as vehicle fitted devices) and interactive digital television. A framework identifying a number of new eMediaries based on the three emerging ePlatforms (Internet, mobile devices and IDTV) is demonstrated in Figure 2. Table 1 also demonstrates examples of traditional and new eMediaries.

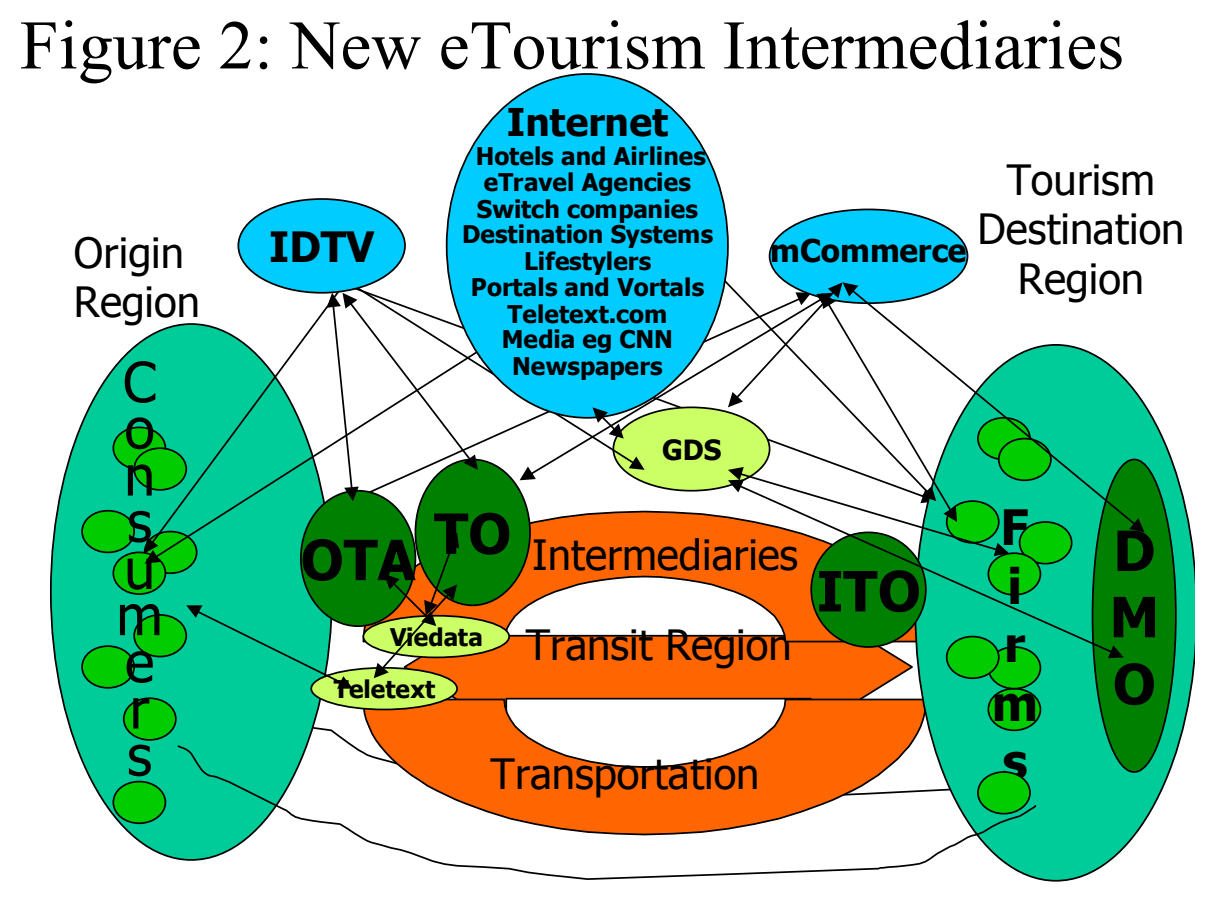

Advanced communication technologies the gradual commercialisation of IDTV (IDTV) and the growing availability of tourism products and services on mobile networks (mCommerce) will intensify competition further. Therefore, traditional eMediaries should re-assess the way they conduct business to ensure that they remain competitive and benefit from the emergent opportunities. Using innovative interfaces, traditionally eMediaries will be able to distribute their products to wider audiences and to enhance their position. This will be increasingly critical in a market that is focusing towards direct marketing and cost/commission cuttings. However the ICT developments will create major problems for organisations that fail to adopt and modernise, as new eMediaries will be competing to maximise their market share by adding value and benefits for both business and leisure end-users. This exploratory research aims to identify the future of both new and traditional eMediaries, and the evolution of their business models as a result of the ICT developments. The research also elaborates on the expected future of traditional and new eMediaries and demonstrates the expected winners and losers in the tourism distribution channel. 
Table 1 Traditional eTourism Intermediaries vs. New eTourism Intermediaries

\begin{tabular}{|c|c|}
\hline $\begin{array}{l}\text { Traditional } \\
\text { eTourism } \\
\text { eMediaries }\end{array}$ & $\begin{array}{l}\text { New } \\
\text { eTourism } \\
\text { eMediaries }\end{array}$ \\
\hline $\begin{array}{l}\text { GDSs } \\
\text { Sabre, } \\
\text { Amadeus, } \\
\text { Galileo, } \\
\text { Worldspan } \\
\text { Viewdata } \\
\text { Teletext }\end{array}$ & 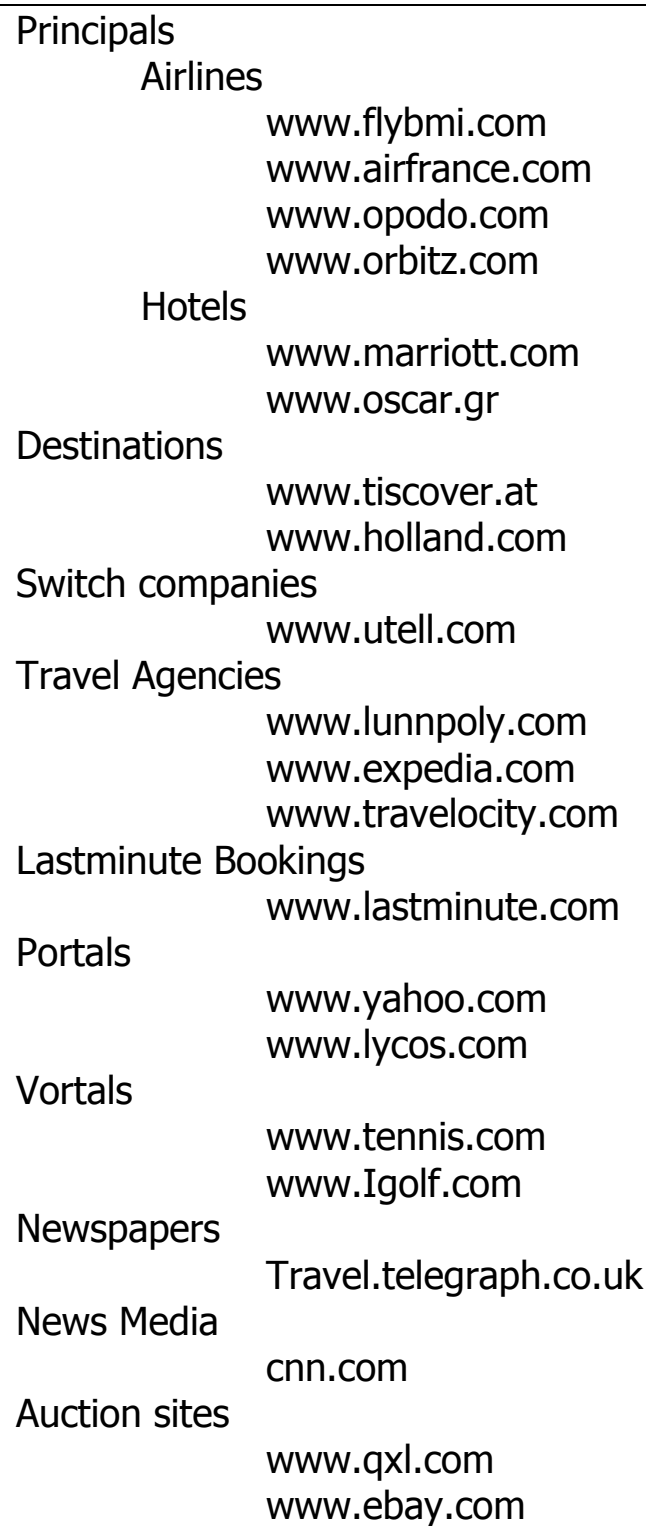 \\
\hline
\end{tabular}

\section{Methodology}

As this is an exploratory research, a qualitative approach was adopted to enable the researchers to appreciate all aspects of the subject and to develop a set of critical variables. Extensive secondary research was used to revise the theoretical framework and also to identify critical areas deserving further investigation. Primary research included both qualitative and quantitative methods. As this is one of the most dynamic areas of both tourism and eCommerce, it was decided to concentrate the primary research only on expert opinion as this would have enabled the identification of longterm trends and provide the research with up-to-today and fairly unbiased evidence. All research activity was undertaken in the UK.

The survey was conducted in three phases, using three primary research tools: an unstructured interview-discussion, a questionnaire and an interview structure. Qualitative interviews with a small number of experts (mainly academics and consultants) helped to obtain more in-depth information 
and clarify points of debate. These experts were identified by their contribution to the literature and also their active participation in international tourism and IT conferences. An unstructured discussion enabled the researchers to interact with participants and to identify critical issues. Based on this activity a questionnaire was drafted, including a number of variables to record experts views and beliefs. The questionnaire contained 14 questions, selected based on the background study, the secondary research and pilot interviews with a select number of experts.

The quantitative survey, allowed to quantify, relate and justify opinions and attitudes of a greater number of people. The questionnaire was e-mailed twice over the period of one month to a total of 62 experts and a total of 30 questionnaires were completed (response rate 49 percent). Quota and judgmental sampling methodologies were used to obtain a pool of possible expert respondents. Experts were chosen as experts on their field and included participants from most tourism industry sectors, such as airlines, hotels, travel agencies, tour operators, as well as consultants and leading academics in the area. The vast majority of the respondents work in the UK, although a few operate overseas. Questionnaire respondents were asked to indicate the level of agreement to particular statements. Given the exploratory nature of this research and the limited number of experts on the field, the number of questionnaires and interviews was assessed as satisfactory.

Following the analysis of the unstructured interviews and questionnaires a further round of qualitative research was undertaken, mainly to qualify, support and appreciate the findings of the quantitative research. This research constituted by a set of follow-up telephone interviews with industry experts, through which more in-depth opinions and comments on the subject were obtained. A standardised but open-ended approach to questioning was used. Certain areas were explored in greater depth, through probing questions not originally included in the interview schedule. Notes were kept on all additional questions asked. Interviews were tape recorded and tapes were listened to at the analysis stage for further input. The interviewees' answers were not influenced by the interviewer's comments. Twenty people were contacted for telephone interviews of which 10 people were interviewed. This sample contained a well-proportioned cross-section of business types: systems suppliers (3), online travel agents (2), a product supplier, a consultancy and GDSs/Leisure Travel Networks (3). The interviews lasted between 30 minutes and 1 hour.

The adopted research methodology offered a great depth of knowledge on the research area and enabled the researchers not only to quantify a number of trends, as perceived by experts, but also to collect a great wealth of qualitative and exploratory information.

\section{Effectiveness of Modern eTourism platforms}

It was considered vital to the purpose of this research to determine the advantages and disadvantages of the emerging ePlatforms used by the new eMediaries, namely the Internet, $\mathrm{m}$ Commerce and Interactive Digital TV, in order to produce a more meaningful comparison with traditional distribution channels.

\subsection{Internet Distribution}

Similarly to Sheldon (1997) and Buhalis (1998), most respondents felt that the Internet gives access to a great number of people, as well as offers the opportunity to develop closer relationships with customers. Respondents felt that the Internet enables consumers to communicate with organisations on a 24 hours, 365 days a year basis and also it enables organisations to implement Customer Relationship Management programs enhancing the opportunities for interaction and a better understanding of both sides. This interaction generates a whole range of new requirements for organisations, as they need to be accessible and available constantly. Hence, calling centres and interactive teams have been developed by a wide range of organisations to support their Internet distribution. Although this is expensive to develop and 
maintain, tourism organisations have reduced their distribution costs and overhead costs. This is because they can afford to pay less commission (or no commission in some airlines' case) to intermediaries and at the same time consumers do the manual work of data entry, instead of employees of the company. The Internet was therefore identified as a clear beneficial distribution platform for principals (Table 2).

Table 2 Advantages of Internet distribution for travel companies

\begin{tabular}{|c|c|c|c|c|c|c|c|c|c|}
\hline & $\begin{array}{c}1 \\
\text { Strongly } \\
\text { disagree }\end{array}$ & $\begin{array}{c}2 \\
\text { Disagree }\end{array}$ & $\begin{array}{c}3 \\
\text { Neutral }\end{array}$ & $\begin{array}{c}4 \\
\text { Agree }\end{array}$ & \begin{tabular}{|c|}
5 \\
Strongly \\
agree
\end{tabular} & No reply & $\begin{array}{c}\text { \# of valid } \\
\text { replies }\end{array}$ & Mean & STD \\
\hline $\begin{array}{l}\text { Greater flexibility } \\
\text { and convenience }\end{array}$ & & $\begin{array}{c}1 \\
3.3 \% \\
\end{array}$ & $\begin{array}{c}7 \\
23.3 \% \\
\end{array}$ & $\begin{array}{c}7 \\
23.3 \% \\
\end{array}$ & $\begin{array}{c}15 \\
50 \% \\
\end{array}$ & & 30 & 4.20 & 0.91 \\
\hline $\begin{array}{l}\text { Increased } \\
\text { penetration and } \\
\text { reach of } \\
\text { customer base }\end{array}$ & & $\begin{array}{c}1 \\
3.3 \%\end{array}$ & $\begin{array}{c}5 \\
16.6 \%\end{array}$ & $\begin{array}{c}13 \\
43.3 \%\end{array}$ & $\begin{array}{c}11 \\
36.6 \%\end{array}$ & & 30 & 4.13 & 0.81 \\
\hline $\begin{array}{l}\text { Lower } \\
\text { distribution costs }\end{array}$ & & $\begin{array}{c}3 \\
10 \% \\
\end{array}$ & $\begin{array}{c}4 \\
13.3 \% \\
\end{array}$ & $\begin{array}{c}13 \\
43.3 \% \\
\end{array}$ & $\begin{array}{c}10 \\
33.3 \% \\
\end{array}$ & & 30 & 4.00 & 0.93 \\
\hline $\begin{array}{l}\text { Increased } \\
\text { customer } \\
\text { interaction }\end{array}$ & & $\begin{array}{c}2 \\
6.6 \%\end{array}$ & $\begin{array}{c}7 \\
23.3 \%\end{array}$ & $\begin{array}{c}14 \\
46.6 \%\end{array}$ & $\begin{array}{c}7 \\
23.3 \%\end{array}$ & & 30 & 3.87 & 0.85 \\
\hline $\begin{array}{l}\text { Easier to Identify } \\
\text { and Target } \\
\text { Customer Base }\end{array}$ & & $\begin{array}{c}2 \\
6.6 \%\end{array}$ & $\begin{array}{c}9 \\
30 \%\end{array}$ & $\begin{array}{c}11 \\
36.6 \%\end{array}$ & $\begin{array}{c}8 \\
26.6 \%\end{array}$ & & 30 & 3.83 & 0.90 \\
\hline $\begin{array}{l}\text { Globalisation of } \\
\text { product }\end{array}$ & & $\begin{array}{c}2 \\
6.6 \% \\
\end{array}$ & $\begin{array}{c}12 \\
40 \% \\
\end{array}$ & $\begin{array}{c}7 \\
23.3 \% \\
\end{array}$ & $\begin{array}{c}9 \\
30 \% \\
\end{array}$ & & 30 & 3.77 & 0.96 \\
\hline $\begin{array}{l}\text { Use of } \\
\text { Multimedia }\end{array}$ & $\begin{array}{c}1 \\
3.3 \%\end{array}$ & $\begin{array}{c}6 \\
20 \% \\
\end{array}$ & $\begin{array}{c}9 \\
30 \%\end{array}$ & $\begin{array}{c}4 \\
13.3 \% \\
\end{array}$ & $\begin{array}{c}9 \\
30 \%\end{array}$ & $\begin{array}{c}1 \\
3.3 \% \\
\end{array}$ & 29 & 3.48 & 1.22 \\
\hline
\end{tabular}

The Internet also enables principals to identify and target customers more accurately and effectively. A wide range of segmentation questions are often asked in the profiling of consumers and specific market segments are frequently diverted to specialised parts of the Internet provision. Respondents representing tour operators and leisure travel networks rated the globalisation of the selling process of the travel product highly. This may be explained by their increasing need to mass-customise their products. Transcending geographical borders allows them to penetrate foreign markets and to embrace a much wider consumer pool towards expanding their market share. Respondents rated the 'use of multimedia' as the least important advantage of the Internet. This can be explained by the current bandwidth restrictions, which do not allow the potential for multimedia content diffusion to be fully realised by industry. However, qualitative research demonstrated that great potential exists for the utilisation of multimedia to convey graphic information and animation about tourism products. This can include videos, maps, interactive presentations etc. Therefore, respondents anticipated that once the technical problems are resolved, tourism organisation would be able to take advantage of the enormous opportunities emerging through multimedia. Broad bandwidth and the Asymmetric Digital Subscriber Line (ADSL) technology will be critical for allowing the transmission of digital information at high bandwidths on existing phone lines for supporting Internet users at home.

As the respondents were tourism and technology professionals, they were expected to advocate ICTs and to find few disadvantages on the Internet. Naturally therefore most respondents disagreed with most of the Internet distribution disadvantages (Table 3). The greatest number of positive answers was for 'Lack of human contact during the interaction' and 'Lack of face-to-face up-sell/cross-sell opportunities'. Respondents felt that since on-line users do not have physical contacts with the actual seller, it is more difficult for the seller to instigate further sales, or to lead the customer to the purchase more expensive or additional products. However, evidence from Scandinavian countries demonstrates that the Internet is more successful in cross-selling as consumers can experiment add extra elements out of their own initiative and enquire on-line without being embarrassed to ask questions. Some interviewees also mentioned that actually the Internet is offering a better service and experience for the consumer as their interaction with 
tourism organisations can be more meaningful. Instead of meeting an inexperienced travel consultant in the high street shop, after having struggled to park and waited in the queue for their turn, a number of travel companies already offer specialised support through their calling centres and enable consumers to ask specific questions to a product/property/destination specialist.

Table 3 - Disadvantages of Internet distribution for travel companies

\begin{tabular}{|c|c|c|c|c|c|c|c|c|}
\hline & $\begin{array}{l}1 \text { Strongly } \\
\text { disagree }\end{array}$ & $\begin{array}{l}2 \\
\text { Disa- } \\
\text { Gree } \\
\end{array}$ & 3 Neutral & $\begin{array}{c}4 \\
\text { Agree }\end{array}$ & $\begin{array}{c}5 \text { Strongly } \\
\text { agree }\end{array}$ & $\begin{array}{l}\text { \# of } \\
\text { valid } \\
\text { replies }\end{array}$ & Mean & $\begin{array}{l}\text { Standard } \\
\text { Deviation }\end{array}$ \\
\hline $\begin{array}{l}\text { Lack of human contact } \\
\text { during the transaction }\end{array}$ & $\begin{array}{c}2 \\
6.6 \% \\
\end{array}$ & $\begin{array}{c}8 \\
26.6 \% \\
\end{array}$ & $\begin{array}{c}8 \\
26.6 \% \\
\end{array}$ & $\begin{array}{c}10 \\
33.3 \% \\
\end{array}$ & $\begin{array}{c}2 \\
6.6 \% \\
\end{array}$ & 30 & 3.07 & 1.06 \\
\hline $\begin{array}{l}\text { Lack of face-to-face up- } \\
\text { sell/cross-sell } \\
\text { opportunities }\end{array}$ & $\begin{array}{c}7 \\
23.3 \%\end{array}$ & $\begin{array}{c}3 \\
10 \%\end{array}$ & $\begin{array}{c}8 \\
26.6 \%\end{array}$ & $\begin{array}{c}10 \\
33.3 \%\end{array}$ & $\begin{array}{c}2 \\
6.6 \%\end{array}$ & 30 & 2.90 & 1.27 \\
\hline Volatile customer base & $\begin{array}{c}7 \\
23.3 \% \\
\end{array}$ & $\begin{array}{c}10 \\
33.3 \% \\
\end{array}$ & $\begin{array}{c}5 \\
16.6 \% \\
\end{array}$ & $\begin{array}{c}6 \\
20 \% \\
\end{array}$ & $\begin{array}{c}2 \\
6.6 \% \\
\end{array}$ & 30 & 2.53 & 1.23 \\
\hline Security issues & $\begin{array}{c}6 \\
20 \% \\
\end{array}$ & $\begin{array}{c}10 \\
33.3 \%\end{array}$ & $\begin{array}{c}10 \\
33.3 \% \\
\end{array}$ & $\begin{array}{c}4 \\
13.3 \% \\
\end{array}$ & & 30 & 2.40 & 0.95 \\
\hline $\begin{array}{l}\text { Danger of standard rather } \\
\text { than tailor-made products }\end{array}$ & $\begin{array}{c}9 \\
30 \% \\
\end{array}$ & $\begin{array}{c}7 \\
23.3 \% \\
\end{array}$ & $\begin{array}{c}8 \\
26.6 \% \\
\end{array}$ & $\begin{array}{c}5 \\
16.6 \% \\
\end{array}$ & $\begin{array}{c}1 \\
3.3 \% \\
\end{array}$ & 30 & 2.40 & 1.17 \\
\hline $\begin{array}{l}\text { Alienation of potential } \\
\text { customers }\end{array}$ & $\begin{array}{c}4 \\
13.3 \% \\
\end{array}$ & $\begin{array}{c}16 \\
53.3 \%\end{array}$ & $\begin{array}{c}10 \\
33.3 \%\end{array}$ & & & 30 & 2.20 & 0.65 \\
\hline $\begin{array}{l}\text { Difficult to market } \\
\text { effectively }\end{array}$ & $\begin{array}{c}14 \\
46.6 \% \\
\end{array}$ & $\begin{array}{c}6 \\
20 \% \\
\end{array}$ & $\begin{array}{c}9 \\
30 \% \\
\end{array}$ & $\begin{array}{c}1 \\
3.3 \% \\
\end{array}$ & & 30 & 1.90 & 0.94 \\
\hline $\begin{array}{l}\text { Difficulty of keeping } \\
\text { records up-to-date }\end{array}$ & $\begin{array}{c}13 \\
43.3 \% \\
\end{array}$ & $\begin{array}{c}9 \\
30 \% \\
\end{array}$ & $\begin{array}{c}7 \\
23.3 \% \\
\end{array}$ & $\begin{array}{c}1 \\
3.3 \% \\
\end{array}$ & & 30 & 1.87 & 0.88 \\
\hline
\end{tabular}

The volatile customer base was often perceived as an opportunity, as experts claimed that organisations can expand their offering to new segments and geographical regions. Security issues were still perceived as significant, but interviews suggested that increasingly consumers who use on-line services appreciate the benefits and realise eCommerce is more secure than many other forms of purchasing. The alienation of potential customers was not perceived as a major problem. Off-line companies, such as Thomas Cook, only enhance their provision for their customers who would like to go on-line, whilst their traditional markets are being maintained. On-line companies such as expedia.com had no off-line customers to alienate and therefore interviewees felt that was not a problem.

The technical capabilities of the competitive tourism organisations improve rapidly. Therefore the updating and maintenance of databases is not seen as a major problem. More advanced and reliable technologies and database packages reduce the need for human operator intervention and allow greater precision in the quality of data. This has been achieved through the automation of product information updating processes and the use of 'intelligent' web forms, where user-entered data can automatically be inserted in databases. In addition, the employment of ICT expects gradually reduces technical problems of this nature and supports organisations to concentrate on their business. Interviewees therefore felt strongly that there was no danger of "standard rather than tailor-made products", "difficulty to market effectively" and "difficulty of keeping records upto-date". Instead they felt that the Internet offers more opportunities for differentiation, for market, products and services development and for taking advantage of records through datawarehousing and data-mining for dynamic marketing.

\subsection{Interactive Digital Television Distribution (IDTV)}

Interviewees appreciated that although the technical capability for IDTV is already available, there are limited commercial applications hitherto. They clearly felt, however, that a new wave of technology will emerge within the next two years and that will have profound effects for the tourism industry. They anticipated that IDTV will revolutionise the travel distribution channel, as it 
will enable easier access and will increase the number of users dramatically. The majority of respondents agreed that IDTV is a 'Wide reaching, populist channel'. Most households already possess a TV set, it is widely used and people have an affiliation with it. They frequently trust their favourite TV channels for their information, news and political debate. IDTV will require a set-top box, which in most cases can be obtained free with the subscription to a digital broadcaster's services (Table 4). Thus, IDTV will be accessible to a greater portion of the population than the Internet and it will allow a greater penetration to the home market as well as to a greater age spectrum. Respondents also agreed that IDTV will probably inspire greater confidence to the online-buyer, as transactions could be perceived to be safer than they would be on the Internet.

Interviewees mentioned that IDTV based tourism distribution benefits from several factors:

- It is a richer communication medium, offering multimedia presentations, video on demand and more realistic footage of destinations and tourism facilities.

- It enables a more relaxed atmosphere than when using the Internet.

- It is interactive and allows video on demand, with full motion pictures and sound.

- It presents content to the family/group rather than simply to the individual and therefore it will be more targeted to the home than the business market.

- It does not need to be switched-on through a procedure.

- It is easy to use and people are already using it habitually.

- It is a commodity.

The relative low rating of most of the IDTV advantages though is related with the existing technical capability of the medium. Respondents felt that the medium has great potential but it is not technically ready yet to fulfil them.

Table 4 Advantages of IDTV as a distribution channel

\begin{tabular}{|c|c|c|c|c|c|c|c|c|}
\hline & $\begin{array}{l}\text { 1 Strongly } \\
\text { disagree }\end{array}$ & 2 Disagree & $\begin{array}{c}3 \\
\text { Neutral }\end{array}$ & $\begin{array}{c}4 \\
\text { Agree }\end{array}$ & $\begin{array}{c}5 \\
\text { Strongly } \\
\text { agree }\end{array}$ & $\begin{array}{c}\# \text { of valid } \\
\text { replies }\end{array}$ & Mean & $\begin{array}{l}\text { Standard } \\
\text { Deviation }\end{array}$ \\
\hline $\begin{array}{l}\text { Wide-reaching, populist } \\
\text { channel }\end{array}$ & $\begin{array}{c}1 \\
3.3 \%\end{array}$ & $\begin{array}{c}2 \\
6.6 \%\end{array}$ & $\begin{array}{c}8 \\
26.6 \%\end{array}$ & $\begin{array}{c}8 \\
26.6 \%\end{array}$ & $\begin{array}{c}11 \\
36.6 \%\end{array}$ & 30 & 3.87 & 1.09 \\
\hline \begin{tabular}{|l|} 
Greater consumer trust \\
compared to Internet
\end{tabular} & $\begin{array}{c}1 \\
3.3 \% \\
\end{array}$ & $\begin{array}{c}6 \\
20 \% \\
\end{array}$ & $\begin{array}{c}9 \\
30 \% \\
\end{array}$ & $\begin{array}{c}10 \\
33.3 \% \\
\end{array}$ & $\begin{array}{c}4 \\
13.3 \% \\
\end{array}$ & 30 & 3.33 & 1.04 \\
\hline \begin{tabular}{|l|} 
Greater flexibility in \\
multimedia presentations
\end{tabular} & $\begin{array}{c}2 \\
6.6 \%\end{array}$ & $\begin{array}{c}7 \\
23.3 \%\end{array}$ & $\begin{array}{c}7 \\
23.3 \%\end{array}$ & $\begin{array}{c}8 \\
26.6 \%\end{array}$ & $\begin{array}{c}6 \\
20 \%\end{array}$ & 30 & 3.30 & 1.22 \\
\hline $\begin{array}{l}\text { Increased customer } \\
\text { interaction }\end{array}$ & $\begin{array}{c}1 \\
3.3 \%\end{array}$ & $\begin{array}{c}11 \\
36.6 \%\end{array}$ & $\begin{array}{c}11 \\
36.6 \%\end{array}$ & $\begin{array}{c}5 \\
16.6 \%\end{array}$ & $\begin{array}{c}2 \\
6.6 \%\end{array}$ & 30 & 2.87 & 0.96 \\
\hline
\end{tabular}

Several respondents also disagreed with the concept of IDTV as a channel that increases customer interaction. Despite the greater possibility for multimedia presentations, IDTV was seen as a "lean backwards"-type media. Customers can sit back and watch what happens on the screen and, to an extent, control it, but not necessarily interact and customise in the same way they would on the Internet. It will be the convergence between different technologies that will change the perception of TV from an entertainment unit to an interactive service station, offering entertainment, information and interaction with the external world. The introduction of the IDTV email for example will gradually force viewers to change their attitude towards TV.

Some interviewees predicted that by the year 2005 they expected that IDTV will dominate leisure travel distribution. Table 5 illustrates the disadvantages of IDTV as a distribution platform. More than half of respondents agreed that it is still developing technologically and, as such, it may not yet be fully functional and ready to be used in the home market on a large scale. Although IDTV usage is currently limited and can reach only a limited customer base, its customer base will expand rapidly in the future. Interviewers explained that it is only a matter of time until the technology has developed to a degree that will enable the full capitalisation of the potential. They 
felt that technological convergence and the expansion of commercial services on IDTV will enable organisations to take advantage of the full potential. ICT will become more advanced, incorporating an increasing number of eCommerce features that will render it superior to the Internet in terms of product information provision and ease of purchase.

Table 5 Disadvantages of IDTV as a distribution channel

\begin{tabular}{|c|c|c|c|c|c|c|c|c|c|}
\hline & $\begin{array}{c}1 \\
\text { Strongly } \\
\text { disagree }\end{array}$ & $\begin{array}{c}2 \\
\text { Disagree }\end{array}$ & \begin{tabular}{|c|}
3 \\
Neutral
\end{tabular} & 4 Agree & $\begin{array}{c}5 \\
\text { Strongly } \\
\text { agree }\end{array}$ & No reply & $\begin{array}{c}\text { \# of valid } \\
\text { replies }\end{array}$ & Mean & $\begin{array}{l}\text { Standard } \\
\text { Deviation }\end{array}$ \\
\hline $\begin{array}{l}\text { Technology still } \\
\text { being developed }\end{array}$ & $\begin{array}{c}1 \\
3.3 \%\end{array}$ & $\begin{array}{c}1 \\
3.3 \%\end{array}$ & $\begin{array}{c}8 \\
26.6 \%\end{array}$ & $\begin{array}{c}11 \\
36.6 \%\end{array}$ & $\begin{array}{c}7 \\
23.3 \%\end{array}$ & $\begin{array}{c}2 \\
6.6 \%\end{array}$ & 28 & 3.79 & 0.98 \\
\hline $\begin{array}{l}\text { Higher cost to } \\
\text { participate }\end{array}$ & $\begin{array}{c}1 \\
3.3 \%\end{array}$ & $\begin{array}{c}3 \\
10 \%\end{array}$ & $\begin{array}{c}8 \\
26.6 \%\end{array}$ & $\begin{array}{c}10 \\
33.3 . \%\end{array}$ & $\begin{array}{c}6 \\
20 \%\end{array}$ & $\begin{array}{c}2 \\
6.6 \%\end{array}$ & 28 & 3.61 & 1.05 \\
\hline $\begin{array}{l}\text { Currently small } \\
\text { customer base } \\
\text { compared to internet }\end{array}$ & $\begin{array}{c}1 \\
3.3 \%\end{array}$ & $\begin{array}{c}4 \\
13.3 \%\end{array}$ & $\begin{array}{c}7 \\
23.3 \%\end{array}$ & $\begin{array}{c}9 \\
30 \%\end{array}$ & $\begin{array}{c}7 \\
23.3 \%\end{array}$ & $\begin{array}{c}2 \\
6.6 \%\end{array}$ & 28 & 3.61 & 1.11 \\
\hline $\begin{array}{l}\text { Less opportunity for } \\
\text { customer interaction }\end{array}$ & $\begin{array}{c}4 \\
13.3 \%\end{array}$ & $\begin{array}{c}8 \\
26.6 \%\end{array}$ & $\begin{array}{c}8 \\
26.6 \%\end{array}$ & $\begin{array}{c}7 \\
23.3 \%\end{array}$ & $\begin{array}{c}1 \\
3.3 \%\end{array}$ & $\begin{array}{c}2 \\
6.6 \%\end{array}$ & 28 & 2.75 & 1.09 \\
\hline $\begin{array}{l}\text { Potentially too much } \\
\text { choice }\end{array}$ & $\begin{array}{c}3 \\
10 \% \\
\end{array}$ & $\begin{array}{c}9 \\
30 \%\end{array}$ & $\begin{array}{c}10 \\
33.3 \% \\
\end{array}$ & $\begin{array}{c}5 \\
16.6 \% \\
\end{array}$ & $\begin{array}{c}1 \\
3.3 \% \\
\end{array}$ & $\begin{array}{c}2 \\
6.6 \%\end{array}$ & 28 & 2.71 & 0.99 \\
\hline Security issues & $\begin{array}{c}6 \\
20 \%\end{array}$ & $\begin{array}{c}12 \\
40 \%\end{array}$ & $\begin{array}{c}9 \\
30 \%\end{array}$ & $\begin{array}{c}1 \\
3.3 \%\end{array}$ & & $\begin{array}{c}2 \\
6.6 \%\end{array}$ & 28 & 2.18 & 0.80 \\
\hline
\end{tabular}

A significant number of respondents (mainly tour operators and high street travel agents) agreed that high cost will prove to be a barrier for companies wishing to participate in IDTV marketing and distribution ventures. High entry cost barriers may favour exclusively larger brands, posing a serious obstacle to smaller companies, especially those operating exclusively on-line. However, with a likely crossover between the Internet and IDTV, this situation may change. Security does not seem to be a major concern for IDTV and a lesser problem than the Internet as the majority of respondents replied negatively to the 'Security issues' options. This confirms the hypothesis that the technology utilised for IDTV transactions will be more advanced than the one used on the Internet, as IDTV will operate in closed networks.

The majority of interviewees perceive IDTV as the "next big thing". They agreed that rather than debating the role of the Internet vs. the one of IDTV, analysts and the tourism industry should concentrate on how to take maximum advantage of the imminent technological convergence. The Internet and IDTV should be considered as enablers and ePlatforms for global travel distribution. Within few years interviewees felt that the two platforms will be complementary and mutually reinforcing, developing the larger eTourism provision. They may potentially aim at different:

- markets and segments: higher socio-economic classes vs. lower income,

- different times: morning/noon/evening/night,

- geographical locations: countries/regions

- uses: business trips vs. leisure products and family holiday

- locations of use: office/home/on the road

Interviewees clearly felt that the two platforms will run in parallel in the future. Naturally 90 percent mentioned the concept of convergence between the two technologies, enabling crosspromotion and cross-navigation. It is predicted therefore that tourism organisations will need to distribute the same content through different ePlatforms. This convergence is going to take place gradually, and will be further enabled by the realisation of interconnectivity between Internet, IDTV and mobile devices. All electronic distribution channels will ultimately be running on enhanced and complementary Internet technologies. Interviewees expected that convergence will produce seamless experiences for the user and it will enable each platform to perform best on its establish strengths. The Internet will be a clear leader in the search, inventory development and transaction front, whilst IDTV is expected to empower the multimedia element which will enable consumers to download and watch real video footage from tourism destinations, products and 
services. One interviewee suggested that IDTV will play a major role in the "inspire" stage, when consumers are seeking inspiration before start searching for their tourism products and experiences.

\subsection{Mobile and mCommerce Distribution}

Although the quantitative part of this research did not go into the issue of eMediaries based on mobile devices and mCommerce, a number of inferences emerged through the qualitative research. Interviewees felt that mobile devices will soon emerge as a major distribution ePlatform for tourism. However, they felt that WAP has failed to fulfil expectations and there is a genuine mistrust currently by consumers. This is attributed to a marketing "over-hype", which promised the "Internet-on-the-go", developing expectations that could not be realistic with the current technology. Interviewees felt that until the $3^{\text {rd }}$ generation (3G) mobile devices arrives sometime in 2005 there will be limited opportunity for travel distribution through this platform.

It is clear that the mCommerce will follow the Internet ePlatform, as a number of Internet-based operators will offer services through different platforms. Tourism providers already use WAP and SMS for distributing information, for allowing consumers to check flight arrivals and departures and for checking in. Examples mentioned include airlines (e.g. Finnair: www.finnair.fi/wap/index.wml), destinations (e.g. Tirol: wap.TIScover.at), electronic Travel Agencies (e.g. Expedia to Go: www.expedia.co.uk) and hotels (e.g. Amari wap.amari.com). Interviewees felt that tourism organisations will expand their Internet provision to support mobile devices once the technology is in place to do that. They felt that the challenge really lies on developing content and information that can be distributed through many different platforms. Perhaps mobile devices will be more useful to business frequent travellers and to people that habitually purchase familiar tourism products, rather to novices that need to search and identify the most suitable product before purchasing. They also identified mCommerce as a great opportunity for last minute sales as well as a medium enabling consumers to make change to reservations near to departure or arrival time.

In addition, interviewees anticipated that telecommunication companies will develop on-line travel services in partnership with electronic Travel Agencies and other suppliers. For example Genie has already developed partnerships with Expedia.com, British Airways and Lastminute.com to enable WAP based tourism distribution. Perhaps the business model will need to change as consumers are willing to pay for getting connected to WAP portals. Therefore tourism organisations may be able to charge telecommunication companies fees for content and therefore share their income from the connection time.

Interviewees felt that mCommerce will be a major change in the way tourism products are distributed as it will support location dependent distribution. mCommerce will also enable consumers to purchase products on the go and at the same time it will enable them to identify the locally available products and services. Similarly mCommerce will allow organisations to target consumers at their proximity and to provide special promotions, offers and services. However, they emphasised that the technical difficulties experienced by $3 G$ developers may delay the commercialisation of these services.

\section{The Future of eTourism intermediaries and Distribution Channels}

Attempting to predict the future of tourism distribution is a difficult task on its own. Aiming at assessing how tourism eMediaries will evolve is even more complex, as on the hand, technological developments emerge rapidly and on the other, tourism distribution is also one of the most dynamic sectors of the industry. Some of the following issues are visioning the future and aiming to identify the major trends and issues. 


\subsection{Distribution Channels and ePlatforms in a 5-Years' Span}

The Internet, IDTV and mobile communication devices were clearly identified as the three most significant ePlatforms for the five-year span (Table 6). They empower consumers to obtain more information, in more detail, in a more independent manner, matching their increased knowledge about destinations and products as well as their sophistication. Interviewees mentioned that technological convergence will enable tourism organisations to use the same content and information to distribute through all three platforms for different markets, users, times, locations and occasions.

The commercial introduction of the Internet has started a process of change in the travel product buying habits of both leisure and business users. The Internet has, indeed, allowed more people to access high quality information quickly and with minimum inconvenience. It also gave the possibility to purchase travel products on-line just as easily. In addition, it generated great service expectations, as consumers anticipate to be served on a 24hours/365days basis and at their own convenience, rather than during the office hours of tourism providers. This trend towards the use of Internet for travel booking is therefore likely to expand and dominate. Several tourism suppliers and particularly no-frills airlines, such as Easyjet and Ryanair, already claim that the majority of their bookings and up to 80 percent is coming from consumers booking directly on-line. Interviewees believed that the initial business travel bias will eventually be followed by the leisure traveller as more consumers will trust the Internet platform to arrange their inventory and as more organisations will develop their offering on-line. Besides on-line travel agents and suppliers, the Internet allows GDSs, which hold the most detailed travel stock databases available, to move closer to end-users. They can do that by either working under their own name or by powering and in some cases owning on-line travel agents (e.g. Sabre/Travelocity.com, Galileo/Trip.com and Worldspan/Expedia.com).

Similarly to the Internet with the business travel market, the introduction of IDTV is likely to have a strong impact on the home/leisure market. Interviewees expect an increasing quantity of onrequest information and booking possibilities, available at the touch of a remote IDTV control button. The trend towards the use of mobile communication devices is mostly determined by the commodification of mobile phones in the past few years, coupled with an increasing need to be able to obtain information while 'on the move'. Already existing mobile technologies enable a certain degree of interaction with tourism suppliers. For example, business travellers can received information on arrivals and departures as well as check-in through their mobile phone for a number of airlines, including British Airways, Swissair and Singapore airlines. The scheduled introduction of advanced mobile technology will enable consumers to access enhanced information, such as customised travel schedules and booking facilities through their mobile phones. The development of the $3^{\text {rd }}$ generation mobile phones incorporating GPRS and UMTS technologies will eventually support comprehensive mCommerce and mService.

The conventional telephone also obtained a high percentage of positive votes. Interviewees felt that despite increasing consumer confidence in on-line booking and support mechanisms, many consumers may still feel happier to confirm their bookings or ask queries by calling a call centre and talking to an operator. In the case of the leisure market, the telephone was regarded an essential method to perform bookings, partly because the on-line Internet provision is not sufficiently developed yet and partly because the majority of the current consumers are not technologically advanced to undertake the purchase of packages on-line. As currently much of the tourism product advertising, carried out through advertisements in the press or even through cable channels such as the TV Travel Shop channel, requires bookings to be made by telephone interviewees felt that conventional telephone will keep playing an important role. This trend will continue. Hence, interviewees felt that the telephone will act as a step between face to face distribution and fully on-line service. 
Table 6 - The most prominent eTourism distribution platforms and channels in 5 years

\begin{tabular}{|c|c|c|c|c|c|c|c|c|c|}
\hline & $\begin{array}{c}1 \text { - } \\
\text { Strongly } \\
\text { disagree }\end{array}$ & \begin{tabular}{|c|}
$2-$ \\
Disagre \\
$e$
\end{tabular} & $\begin{array}{c}\text { 3- } \\
\text { Neither } \\
\text { Agree nor } \\
\text { Disagree }\end{array}$ & $\begin{array}{c}4- \\
\text { Agree }\end{array}$ & $\begin{array}{c}5- \\
\text { Strongly } \\
\text { agree }\end{array}$ & $\begin{array}{l}\text { No } \\
\text { reply }\end{array}$ & $\begin{array}{c}\text { \# of valid } \\
\text { replies }\end{array}$ & Mean & $\begin{array}{l}\text { Standard } \\
\text { Deviation }\end{array}$ \\
\hline \multicolumn{10}{|c|}{ EFuture Platforms } \\
\hline Internet & & & $\begin{array}{c}1 \\
3.3 \%\end{array}$ & $\begin{array}{c}7 \\
23.3 \%\end{array}$ & $\begin{array}{c}22 \\
73.3 \%\end{array}$ & & 30 & 4.70 & 0.53 \\
\hline Interactive TV & & $\begin{array}{c}2 \\
6.6 \%\end{array}$ & $\begin{array}{c}7 \\
23.3 \%\end{array}$ & $\begin{array}{c}7 \\
23.3 \%\end{array}$ & $\begin{array}{c}14 \\
46.6 \%\end{array}$ & & 30 & 4.10 & 0.98 \\
\hline $\begin{array}{l}\text { Mobile } \\
\text { Phones/ } \\
\text { Portable } \\
\text { communicatio } \\
\text { n devices }\end{array}$ & & $\begin{array}{c}3 \\
10 \%\end{array}$ & $\begin{array}{c}4 \\
13.3 \%\end{array}$ & $\begin{array}{c}12 \\
40 \%\end{array}$ & $\begin{array}{c}11 \\
36.6 \%\end{array}$ & & 30 & 4.03 & 0.95 \\
\hline \multicolumn{10}{|c|}{ eConventional Platforms } \\
\hline $\begin{array}{l}\text { Conventional } \\
\text { telephone }\end{array}$ & $\begin{array}{c}1 \\
3.3 \%\end{array}$ & $\begin{array}{c}1 \\
3.3 \%\end{array}$ & $\begin{array}{c}8 \\
26.6 \%\end{array}$ & $\begin{array}{c}10 \\
33.3 \%\end{array}$ & $\begin{array}{c}9 \\
30 \%\end{array}$ & $\begin{array}{c}1 \\
3.3 \%\end{array}$ & 29 & 3.86 & 1.01 \\
\hline GDS & & $\begin{array}{c}3 \\
10 \%\end{array}$ & $\begin{array}{c}11 \\
36.6 \%\end{array}$ & $\begin{array}{c}8 \\
26.6 \%\end{array}$ & $\begin{array}{c}6 \\
20 \%\end{array}$ & $\begin{array}{c}2 \\
6.6 \%\end{array}$ & 28 & 3.61 & 0.94 \\
\hline $\begin{array}{l}\text { High street } \\
\text { shops }\end{array}$ & $\begin{array}{c}1 \\
3.3 \%\end{array}$ & $\begin{array}{c}4 \\
13.3 \%\end{array}$ & $\begin{array}{c}11 \\
36.6 \%\end{array}$ & $\begin{array}{c}8 \\
26.6 \%\end{array}$ & $\begin{array}{c}5 \\
16.6 \%\end{array}$ & $\begin{array}{c}1 \\
3.3 \%\end{array}$ & 29 & 3.41 & 1.03 \\
\hline $\begin{array}{l}\text { Self service } \\
\text { kiosk }\end{array}$ & $\begin{array}{c}1 \\
3.3 \%\end{array}$ & $\begin{array}{c}10 \\
33.3 \%\end{array}$ & $\begin{array}{c}6 \\
20 \%\end{array}$ & $\begin{array}{c}9 \\
30 \%\end{array}$ & $\begin{array}{c}2 \\
6.6 \%\end{array}$ & $\begin{array}{c}2 \\
6.6 \%\end{array}$ & 28 & 3.04 & 1.05 \\
\hline Viewdata & $\begin{array}{c}9 \\
30 \%\end{array}$ & $\begin{array}{c}11 \\
36.6 \%\end{array}$ & $\begin{array}{c}3 \\
10 \%\end{array}$ & $\begin{array}{c}3 \\
10 \%\end{array}$ & & $\begin{array}{c}4 \\
13.3 \%\end{array}$ & 26 & 2.00 & 0.96 \\
\hline
\end{tabular}

A further significant percentage of respondents believe that GDSs will still play an important role in the 5 years' time frame. Although many new emerging competitors may pose a threat to the supremacy of GDSs, they have reacted to the former by creating alliances with on-line travel agents and by offering a new range of products. Hence interviewees felt that GDSs are already the backbone for most Internet-enabled distribution and they predicted that their role will change from travel agency supporters to eMediary-facilitators, often working in the background. Others suggested that GDSs initiatives to develop consumer interfaces will also strengthen their position.

As for the distribution channels that are going to lose ground in the next five years, the results of the survey showed that respondents felt that, above all others, Viewdata is the distribution channel that will not survive. There are four reasons behind this choice: Firstly, Viewdata is a tool principally used by high street travel agents and is not aimed directly at the consumer. Thus, if traditional high street travel agents are partially disintermediated, as many believe they will be, there will no longer be a profitable market for Viewdata to operate, and ultimately no conditions for it to exist. Secondly, the Viewdata technology is regarded as rather outdated. Its interface is not user-friendly, it is slow and information needs to be entered every time a query is made. For this reason, competitive travel agents as well as competitive Viewdata providers (e.g. Imminus/Telewest) are expected to opt for new, more customisable, Windows-based systems that will use Internet interfaces to facilitate interaction with tour operators and other suppliers. Thirdly, consumers increasingly bring to travel agencies printouts from the Internet, either from the same company (e.g. ThomasCook.com) or competitors (e.g. Expedia.com) and request travel agencies to either match the offer they hold or to do the actual booking for them. Unless agencies have Internet compatible computers they will be unable to fulfil the demand. Finally tour operators will eventually impose a move from legacy systems to more advanced technologies which will be unable to communicate with Viewdata terminals. This move would enable better functionality, access to information available to consumers through the Internet, and interactivity. 


\subsection{Distribution Channels and ePlatforms in a 15-Years' Span}

Speculating for a 15-year span is really dangerous in this fast-moving environment. However this survey aimed at exploring where experts felt that electronic tourism distribution will be going in the long term, recognising the dangers of being helplessly outdated only few years later. The results of this enquiry show an interesting correlation with the 5-year prediction results. From the responses obtained (Table 7) the most evident change is in the Mobile phones/Portable communication devices field. The overwhelming majority of respondents believed mobile eMediaries will play an important role in tourism distribution in the next 15 years. Interviewees felt that consumer will eventually have an even greater need to access information, and hence make bookings, from any place, individually, rather than from a static location. Users are expected to request and receive relevant travel information and holiday offers on mobile devices, from operators that offer this service.

Table 7 - The most prominent distribution platforms and channels in 15 years

\begin{tabular}{|c|c|c|c|c|c|c|c|c|c|}
\hline & $\begin{array}{l}\text { - } \\
\text { Strongly } \\
\text { disagree }\end{array}$ & $\begin{array}{l}2- \\
\text { Disagre } \\
\text { e }\end{array}$ & \begin{tabular}{|l}
$3-$ \\
Neither \\
Agree \\
nor \\
Disagre \\
e
\end{tabular} & $\begin{array}{l}\text { Agree } \\
\text { Agre }\end{array}$ & \begin{tabular}{|l|}
$5-$ \\
Strongly \\
agree
\end{tabular} & No reply & $\begin{array}{c}\text { \# of } \\
\text { valid } \\
\text { replies }\end{array}$ & Mean & $\begin{array}{l}\text { Standard } \\
\text { Deviation }\end{array}$ \\
\hline \multicolumn{10}{|c|}{ eFuture Platforms } \\
\hline $\begin{array}{l}\text { Mobile } \\
\text { Phones/ } \\
\text { Portable } \\
\text { communicati } \\
\text { on devices } \\
\end{array}$ & & & & $\begin{array}{c}9 \\
30 \%\end{array}$ & $\begin{array}{c}18 \\
60 \%\end{array}$ & $\begin{array}{c}3 \\
10 \%\end{array}$ & 27 & 4.67 & 0.47 \\
\hline $\begin{array}{l}\text { Interactive } \\
\text { TV }\end{array}$ & & $\begin{array}{c}1 \\
3.3 \%\end{array}$ & $\begin{array}{c}2 \\
6.6 \%\end{array}$ & $\begin{array}{c}4 \\
13.3 \%\end{array}$ & $\begin{array}{c}20 \\
66.6 \%\end{array}$ & $\begin{array}{c}3 \\
10 \%\end{array}$ & 27 & 4.59 & 0.78 \\
\hline Internet & & $\begin{array}{c}1 \\
3.3 \%\end{array}$ & $\begin{array}{c}1 \\
3.3 \%\end{array}$ & $\begin{array}{c}8 \\
26.6 \%\end{array}$ & $\begin{array}{c}17 \\
56.6 \%\end{array}$ & $\begin{array}{c}3 \\
10 \%\end{array}$ & 27 & 4.52 & 0.74 \\
\hline \multicolumn{10}{|c|}{ eConventional Platforms } \\
\hline $\begin{array}{l}\text { Self service } \\
\text { kiosk }\end{array}$ & $\begin{array}{c}5 \\
16.6 \%\end{array}$ & $\begin{array}{c}5 \\
16.6 \%\end{array}$ & $\begin{array}{c}7 \\
23.3 \%\end{array}$ & $\begin{array}{c}7 \\
23.3 \%\end{array}$ & $\begin{array}{c}2 \\
6.6 \%\end{array}$ & $\begin{array}{c}4 \\
13.3 \%\end{array}$ & 26 & 2.85 & 1.23 \\
\hline $\begin{array}{l}\text { High street } \\
\text { shops }\end{array}$ & $\begin{array}{c}2 \\
6.6 \%\end{array}$ & $\begin{array}{c}10 \\
33.3 \%\end{array}$ & $\begin{array}{c}8 \\
26.6 \%\end{array}$ & $\begin{array}{c}5 \\
16.6 \%\end{array}$ & $\begin{array}{c}1 \\
3.3 \%\end{array}$ & $\begin{array}{c}4 \\
13.3 \%\end{array}$ & 26 & 2.73 & 0.98 \\
\hline $\begin{array}{l}\text { Conventional } \\
\text { telephone }\end{array}$ & $\begin{array}{c}5 \\
16.6 \%\end{array}$ & $\begin{array}{c}5 \\
16.6 \%\end{array}$ & $\begin{array}{c}10 \\
33.3 \%\end{array}$ & $\begin{array}{c}4 \\
13.3 \%\end{array}$ & $\begin{array}{c}2 \\
6.6 \%\end{array}$ & $\begin{array}{c}4 \\
13.3 \%\end{array}$ & 26 & 2.73 & 1.16 \\
\hline GDS & $\begin{array}{c}2 \\
6.6 \%\end{array}$ & $\begin{array}{c}12 \\
40 \%\end{array}$ & $\begin{array}{c}5 \\
16.6 \%\end{array}$ & $\begin{array}{c}6 \\
20 \%\end{array}$ & $\begin{array}{c}1 \\
3.3 \%\end{array}$ & $\begin{array}{c}4 \\
13.3 \%\end{array}$ & 26 & 2.69 & 1.03 \\
\hline Viewdata & $\begin{array}{c}23 \\
76.6 \%\end{array}$ & $\begin{array}{c}1 \\
3.3 \%\end{array}$ & $\begin{array}{c}1 \\
3.3 \%\end{array}$ & & & $\begin{array}{c}5 \\
16.6 \%\end{array}$ & 25 & 1.12 & 0.43 \\
\hline
\end{tabular}

Another interesting result emerging from the survey is a marked decrease in positive answers for the Internet, which could be correlated to a slight increase in positive answers for IDTV. A crossover between the Internet and IDTV might result to a greater penetration of the home market. This may justify an increase in the use of IDTV as a distribution channel for leisure users, with the Internet remaining, through the use of intranets and extranets, as an established distribution channel for business-to-business travel solutions. Interviewees felt that capabilities of both mobile devices and IDTV will outperform the Internet but several mentioned that in 15 years time it will be difficult to separate the different ePlatforms. 
Respondents felt that self-service kiosks and high street shops may still perform a role and interviewees felt strongly that high street travel agencies will continue exist. They anticipated however that they will change to holiday shops providing a holiday experience, integrated and comprehensive service and a much more personalised advice. GDSs as well as Viewdata systems and the conventional telephone recorded a higher negative response rate than in the five year time frame. This indicates that these more conventional forms of distribution are likely to be bypassed or radically change their operations in order to serve a more 'wired' and sophisticated marketplace. While GDSs were not expected to be driven out of the market, experts felt that their role is expected to change dramatically to provide the backbone for the travel distribution and to power tourism eMediaries solutions and services, rather than support travel agencies.

\section{The Changing Role of the Traditional Travel eMediaries}

The need for modernisation and the entrance of new competitors in the market influence the future of traditional electronic distribution channels (Table 8). Traditional eMediaries (GDSs, Viewdata, Teletext) therefore need to change roles and to develop new competencies. Many respondents believe that GDSs, leisure travel networks and tour operators will move one step closer to the consumer, and sell directly to them. GDSs will retain their role as suppliers of booking systems to travel agents but their core competencies will probably shift from this role. Interviewees felt that the future of GDS lies in providing the backbone to future eMediaries. Their establish procedures for inventory building, ticketing, income clearing and distribution to suppliers are in the centre of eCommerce for the tourism industry.

Many interviewees also felt that traditional travel eMediaries will start distributing more than just travel products in order to add value to their offering, by providing content and ancillary services. Interviewees felt that personalising the tourism product will be critical for the successful eMediaries of the future. This will be achieved by outsourcing several functions and services to external companies and through establishing partnerships with other suppliers insourcing elements that can add value for the customer. They will need therefore to develop and offer 'one-stopshops' for users. This will enable them to maximise revenue from their customers, while at the same time maintaining an edge against Web portals such as Yahoo! and other new comers to the travel retail market, such as vortals and auction sites. They will also develop their ability to crosssell travel-related products (such as travel guides, accessories etc.). This will be particularly feasible for GDSs that own or have realised collaborations with on-line travel agents.

Most interviewees (70 percent) suggested that instead of the widely reported disintermediation of the traditional distribution channels they expected a re-intermediation. As new on-line travel agencies enter the market offering value-added products and customisable user features, many of the traditional eMediaries will reinvent themselves to adopt to the new realities. 
Table 8 Statements on the Changing Role of the eTourism intermediaries

\begin{tabular}{|c|c|c|c|c|c|c|c|c|c|}
\hline & \begin{tabular}{|c|}
1 \\
Strongly \\
disagree
\end{tabular} & \begin{tabular}{|c|}
2 \\
Disagre \\
$\mathbf{e}$ \\
\end{tabular} & \begin{tabular}{|c|}
3 \\
Neutra \\
I
\end{tabular} & $\begin{array}{c}4 \\
\text { Agree }\end{array}$ & \begin{tabular}{|c|}
5 \\
Strongly \\
agree
\end{tabular} & No reply & $\begin{array}{c}\text { \# of } \\
\text { valid } \\
\text { replies }\end{array}$ & Mean & $\begin{array}{l}\text { Standard } \\
\text { Deviation }\end{array}$ \\
\hline $\begin{array}{l}\text { The traditional travel } \\
\text { eMediaries will } \\
\text { increasingly sell directly } \\
\text { to the customer }\end{array}$ & & $\begin{array}{c}2 \\
6.6 \%\end{array}$ & $\begin{array}{c}5 \\
16.6 \%\end{array}$ & $\begin{array}{c}13 \\
43.3 \%\end{array}$ & $\begin{array}{c}9 \\
30 \%\end{array}$ & $\begin{array}{c}1 \\
3.3 \%\end{array}$ & 29 & 4.00 & 0.87 \\
\hline $\begin{array}{l}\text { The traditional travel } \\
\text { eMediaries will start } \\
\text { distributing more than } \\
\text { just travel products }\end{array}$ & & $\begin{array}{c}3 \\
10 \%\end{array}$ & $\begin{array}{c}10 \\
33.3 \%\end{array}$ & $\begin{array}{c}8 \\
26.6 \%\end{array}$ & $\begin{array}{c}7 \\
6.6 \%\end{array}$ & $\begin{array}{c}2 \\
6.6 \%\end{array}$ & 28 & 3.68 & 0.97 \\
\hline $\begin{array}{l}\text { On-line travel agents will } \\
\text { increasingly connect } \\
\text { directly with travel } \\
\text { suppliers, bypassing the } \\
\text { GDSs }\end{array}$ & & $\begin{array}{c}1 \\
3.3 \%\end{array}$ & $\begin{array}{c}14 \\
46.6 \%\end{array}$ & $\begin{array}{c}8 \\
26.6 \%\end{array}$ & $\begin{array}{c}6 \\
20 \%\end{array}$ & $\begin{array}{c}1 \\
3.3 \%\end{array}$ & 29 & 3.66 & 0.84 \\
\hline $\begin{array}{l}\text { The GDSs will be } \\
\text { increasingly bypassed by } \\
\text { travel suppliers } \\
\text { distributing directly on } \\
\text { the Internet }\end{array}$ & & $\begin{array}{c}6 \\
20 \%\end{array}$ & $\begin{array}{c}11 \\
36.6 \%\end{array}$ & $\begin{array}{c}9 \\
30 \%\end{array}$ & $\begin{array}{c}3 \\
10 \%\end{array}$ & $\begin{array}{c}1 \\
3.3 \%\end{array}$ & 29 & 3.31 & 0.91 \\
\hline $\begin{array}{l}\text { The Leisure Travel } \\
\text { Networks will increasingly } \\
\text { be bypassed by direct } \\
\text { distribution on the } \\
\text { Internet }\end{array}$ & $\begin{array}{c}1 \\
3.3 \%\end{array}$ & $\begin{array}{c}5 \\
16.6 \%\end{array}$ & $\begin{array}{c}11 \\
36.6 \%\end{array}$ & $\begin{array}{c}8 \\
26.6 \%\end{array}$ & $\begin{array}{c}4 \\
13.3 \%\end{array}$ & $\begin{array}{c}1 \\
3.3 \%\end{array}$ & 29 & 3.31 & 1.02 \\
\hline $\begin{array}{l}\text { The traditional travel } \\
\text { eMediaries will become } \\
\text { less concerned with } \\
\text { servicing travel agents }\end{array}$ & & $\begin{array}{c}7 \\
23.3 \%\end{array}$ & $\begin{array}{c}10 \\
33.3 \%\end{array}$ & $\begin{array}{c}8 \\
26.6 \%\end{array}$ & $\begin{array}{c}4 \\
13.3 \%\end{array}$ & $\begin{array}{c}1 \\
3.3 \%\end{array}$ & 29 & 3.31 & 0.99 \\
\hline $\begin{array}{l}\text { The traditional travel } \\
\text { eMediaries will } \\
\text { increasingly be bypassed } \\
\text { by tour operator } \\
\text { reservation system } \\
\text { suppliers developing their } \\
\text { own distribution systems }\end{array}$ & $\begin{array}{c}3 \\
10 \%\end{array}$ & $\begin{array}{c}5 \\
16.6 \%\end{array}$ & $\begin{array}{c}12 \\
40 \%\end{array}$ & $\begin{array}{c}7 \\
23.3 \%\end{array}$ & $\begin{array}{c}2 \\
6.6 \%\end{array}$ & $\begin{array}{c}1 \\
3.3 \%\end{array}$ & 29 & 3.00 & 1.05 \\
\hline
\end{tabular}

While traditional off-line agencies will progressively lose a share of their market, there will always be a need for an aggregator of holiday packages, flights and travel advice. Thus traditionally eMediaries will need to modernise and use on-line tools to address the emerging market. Teletext was mentioned by one interviewee as a prime example of an organisation that is gradually migrating on the Internet, enhancing their service and attracting new customers. High street agents are expected to retain a larger market share in low-margin package holidays. This is likely to remain unchanged until Interactive Digital TV becomes more widespread. However, interviewees predicted that flight bookings will be increasingly served by on-line agencies and airlines selling directly to consumers, using their own on-line reservation systems. Customer Relationship Management systems, special offers and frequent flyer clubs will all offer incentives to consumers to purchase flights directly. Therefore interviewees predicted that the successful eMediaries of the future will adopt a "clicks and mortal" strategy where a "click-in" (Internet and mCommerce), "call-in" (supported by calling centres) and "step-in" (high street presence) will dominate.

\section{Conclusions: The Rise of New eMediaries and the future of traditional eMediaries}

The use of new distribution channels and the launch of value-added services and features across all ePlatforms and distribution channels are clearly identified as the main factors affecting the competitiveness of all tourism intermediaries. New eMediaries (e.g. on-line travel agents, portals) 
in the electronic distribution market challenge traditional eMediaries (e.g. GDSs and Viewdata) as they gradually penetrate the marketplace, gain direct access to consumers and increase their marketshare. The timely delivery of relevant, content-rich information was identified by interviewees as one of the main differentiating factors in the on-line market. Traditional eMediaries, in contrast, offer limited added-value features, content, availability information and booking functionality. Respondents clearly indicated that they anticipate that new eMediaries will be taking advantage of their capabilities and will increase their presence in the marketplace. In contrast, traditional eMediaries will have to either modernise and adopt to the new realities by developing their on-line presence or face significant loses in their market share and value.

The commercial introduction and subsequent potential take-off of tourism services based on IDTV and mobile technology will enable new eMediaries to achieve a further penetration of both the home and business markets. The eminent convergence of the Internet, IDTV and mobile telephony will provide a further competitive advantage for new eMediaries as they will be adopting a multi-platform approach to serve different users at different times and situations.

However, the proliferation of new eMediaries, coupled with weaknesses in the current business model of many of these, may hinder their competitiveness. Companies developing tourism applications to become available through the Internet, IDTV and mobile devices are often young and inexperienced in this market. Their links with suppliers may therefore be volatile, especially if they are not able to achieve significant volume of bookings within a fairly short time. Drawing financial resources for developing systems is also a major resource issue as successful eMediaries normally do not break even for at least 4-5 years. New eMediaries need to develop their distinct branding and establish their presence in an increasingly competitive marketplace. Moreover, although the cost of start-up for on-line businesses can be relatively low, adopting a multi-channel strategy and expanding into IDTV and mobile platforms may prove prohibitively expensive for many small companies.

New eMediaries currently have a competitive edge over traditional eMediaries, on the on-line market. However, tourism suppliers, such as airlines and hotel chains, as well as destinations and traditional intermediaries such as travel agencies and tour operators bring resources together and develop their on-line provision. New eMediaries therefore need to building relationships with suppliers and to use the entire range of ePlatforms to service their customers. Provided that the right alliances are made, this would also minimise costs and maximise revenues through commissions. eTourism is still in its infancy and it is widely predicted to be one of the most rapidly expanding industries on-line. Inevitably new eMediaries will therefore go through a natural selection process, which will separate the stronger players - ones with sound business models, stability and the possibility to expand on all distribution channels and platforms available - from those that will fail. Success will probably depend on the ability of organisations to target the most appropriate niches and to form partnerships that enhance fulfil the need of the marketplace, image and increase market share. Being able to fulfil customer expectations and providing comprehensive and coherent service will be critical.

Disintermediation poses a threat to traditional eMediaries. In the case of Viewdata, respondents believed that it is going to be gradually phased out in the next five years. Teletext has already established its online presence on the Internet and therefore it is already refocusing its distribution. However innovative traditional eMediaries can also take advantage of their established brands and develop their on-line presence to communicate directly with their clientele. The results showed that a significant cross-section of respondents believed GDSs run the risk of being bypassed by smaller inventory services, such as those utilised by web-based travel agents and suppliers. These, although more limited in terms of information, are much cheaper to run than the GDSs. However, respondents believe that GDSs would still play an important role in the next five and fifteen years. The rapid technological developments and the emergence of the Internet demonstrate that they will need to modernise and refocus their operations if they are to survive in 
the future. Two possible compatible rather than mutually exclusive currents of thought were identified:

- Firstly, those who believe that GDSs are destined to give up much of their current powers and supremacy and will simply become high-speed switches or host systems on behalf of travel suppliers. GDSs should be regarded not as distribution channels but as enablers, providing interconnectivity between suppliers and travel distributors. Some interviewees supported therefore that GDSs will probably re-emerge as the backbone of the tourism distribution, supporting a entire range of eMediaries with a distribution mechanism. Smaller GDSs will probably be consolidated, hence reducing the number of large players in the market to only two or three globally.

- Secondly, some interviewees felt that GDSs have the potential to capture a significant share of the direct-to-customer market and to establish themselves as providers of travel products with an emphasis on the business market. They suggested that GDSs should also adopt a multichannel distribution approach, endorsing and supporting all the technologies chosen by customers and developing their on-line presence. This can be achieved by interfacing legacy systems for the front-end Internet sites and by introducing more content rather than just providing a repository service for travel itineraries.

There is one point that all respondents agreed upon: there is great change ahead and only competitive, flexible and dynamic eMediaries will use both old and new ePlatforms to survive and expand in the future. Mergers, alliances, partnerships, re-developments will all be used regularly to enable partners to remain competitive. Inevitably there will be several winners who will use all available ePlatforms to deliver products in the most suitable way for their market segments. However, a large proportion of players will fail to modernise fast enough to develop suitable business models and market propositions. These players will probably suffer catastrophic consequences. The only winner in the future will be the consumer as well as principals and intermediaries that will adopt a dynamic, flexible and innovative strategic and tactical management.

\section{References}

Archdale, G. (1996). The Internet in Context, Insights, July, 1-7

Bordat, P. (1999). Repositioning a GDS for Future Electronic Markets, ENTER 99 conference proceedings, 20-23 January, Innsbruck, Austria (http://www.ifitt.org/enter- 09/05/2000)

Buhalis, D. and Laws, E. (2001). Tourism Distribution Channels, Continuum, London.

Buhalis, D. (2000). Tourism and Information technologies: Past, Present and Future, Tourism Recreation Research, 25(1), 41-58

Buhalis, D. (1998). Strategic Use of Information Technologies in the Tourism Industry, Tourism Management, 19(5), 409-421

Buhalis, D. A.M. Tjoa, Jafari, J. (eds). (1998). Information and communication technologies in tourism, Springer-Verlag, Wien.

Buhalis, D. Schertler, W. (eds). (1999). Information and communication technologies in tourism, Springer-Verlag, Wien.

Copeland, D. (1991). So you want to build the next SABRE System, Business Quarterly, 55(33), 56-60.

Copeland, D. and McKenney, J. (1988). Airline reservation systems: Lessons from history, MIS Quarterly, 12, 535-370.

Fesenmaier, D. Klein, S. Buhalis, D. (eds). (2000). Information and Communication Technologies in Tourism, Springer, Vienna

French, T. (1998). The future of Global Distribution Systems, Travel and Tourism Analyst, no.3, 117. 
Hawkins, D. E. Leventhal, M. \& Oden, W. L. (1996). The Virtual Tourism Environment. Utilisation of Information Technology to Enhance Strategic Travel Marketing, Progress in Tourism and Hospitality Research, 2, 223-238

Kärcher, K. (1996). The four Global Distribution Systems in the travel and tourism industry, Electronic Markets, 6(2), 20-24.

Kärcher, K. (1998). Tour Operators in the Electronic Marketplace, ENTER 98 conference proceedings, 21-23 January 1998 (http://wWw.ifitt.org/enter/ - 09/05/00)

Kärcher, K. (1997). Reinventing the package holiday business: new information and telecommunications technologies, DeutscherUniversitatsVerlag, Gabler, Germany.

Leiper, N. (1995). Tourism Management, RMIT Press, Melbourne.

O'Connor, P. (1999). Electronic Information Distribution in Tourism \& Hospitality, CAB, Oxford.

O'Connor, P. and Frew, A. (2000). Evaluating electronic channels of distribution in the hotel sector: A Delphi study, Information Technology and Tourism, 3(3/4), 177-193.

Poon, A. (1993). Tourism, Technology and Competitive Strategies, Oxford: CAB International

Porter, M. (1985). Technology and competitive advantage, The Journal of Business Strategy, Winter, 60-70.

Porter, M. (2001). Strategy and the Internet, Harvard Business Review, March, 79(3), 63-78

Porter, M. and Millar, V. (1985). How information gives you competitive advantage, Harvard Business Review, July-August, 63(4), 149-160.

Richer, P. \& ONeill-Dunne, T. (1999). Distribution Technology in the Travel Industry Strategies for Marketing Success, London: FINANCIAL TIMES Retail \& Consumer

Sheldon, P. J. (1997). Tourism Information Technology, Oxford: CAB International.

Sheldon, P. Wöber, K, Fesenmaier, D. (eds), (2001). Information and Communication Technologies in Tourism, Springer, Vienna

Smith, C. and Jenner, P. (1998). Tourism and the Internet, Travel and Tourism Analyst, no.1, 62-81.

Truitt, L. Teye, V. Farris, M. (1991). The role of Computer Reservation Systems: international implications for the tourism industry, Tourism Management, 12(1), 21-36

Werthner, H. and Klein, S. (1999). Information Technology and Tourism-A challenging relationship, Springer, New York.

WTO, (1995). Global Distribution Systems in the tourism Industry, Madrid: World Tourism Organisation. 